\title{
Mature Students Using Mobile Devices in Life and Learning
}

\author{
Agnes Kukulska-Hulme, The Open University, UK \\ John Pettit, The Open University, UK \\ Linda Bradley, Chalmers University of Technology, Sweden \\ Ana A. Carvalho, University of Minho, Portugal \\ Anthony Herrington, Curtin University, Australia \\ David Kennedy, University of Hong Kong, Hong Kong \\ Aisha Walker, University of Leeds, UK
}

\begin{abstract}
The paper reports on research concerned with learners'uses of mobile technologies based on an international survey that targeted students registered in selected master's and doctoral programmes in Australia, Hong Kong, Portugal, Sweden, and the United Kingdom. The survey findings were enriched by local knowledge, as the authors administered questionnaires in their own countries. The research gives an account of uses of handheld devices by students from departments of education, educational technology, engineering, and information technology in the domains of learning, work, social interaction and entertainment. The paper illuminates learners' choices in the midst of evolving social practices, and challenges the common preconception that mobile devices are not suitable for academic study. In today's global education marketplace, educators must know the technology habits and expectations of their students, including those from other countries. Knowing about students' previous practices and the techno-cultural setting they come from can help institutions determine what mobile applications are most appropriate to support learning.
\end{abstract}

Keywords: Communities, Higher Education, Informal Learning, Learner-Driven Innovation, Online Survey, Mature Students, Work-Life Boundaries

\section{INTRODUCTION}

Recent reflection on technology-enhanced learning and teaching suggests a key design principle, that "Learners can be active makers and shapers of their own learning. They should

DOI: $10.4018 / \mathrm{jmbl} .2011010102$ be supported in using technologies of their own choice where appropriate" (JISC, 2009, p. 51). Learners might choose technologies that are familiar to them and that they have used successfully in the past. This could include mobile devices, although for many people such a choice would be a departure from their usual practice of using mobile phones and other portable 
devices for personal and social reasons, rather than learning. That is why the circumstances in which learners decide to use a mobile device, for learning and for other aspects of their lives, are worth investigating.

It has been shown that an everyday tool such as the mobile phone will not necessarily be readily adopted for learning; a variety of barriers to adoption continue to be identified, such as ergonomic, pedagogical, psychological and environmental factors and the issue of cost (Stockwell, 2008). At the same time, it is clear that some barriers are local, temporary and may be overcome. For example, since mobile device users are driving the proliferation of free $\mathrm{Wi}-\mathrm{Fi}$ hotspots in parts of the world (Bradford, 2010), cost issues could become less of a barrier, and we can speculate that more widespread adoption by students and teachers is likely to follow. Furthermore, the increasing availability of free or inexpensive 'apps' (applications) for mobile phones is also spreading the message that the phone can be used as a convenient and powerful tool for learning.

Due to the rapidly changing landscape of technology use, there is a continual need to understand learner practices and their technology adoption, including any new barriers and enablers that can be identified. In an age when "communities are jumping across technologies" as needs and trends evolve (Wenger, 2010), educators and researchers also have to stay informed about how learners use personal technologies as members of communities that may be social, work-related or educational. Communities and networks facilitated by technology are, in turn, the means by which various technologies are promulgated and adopted; for example, when social network sites add real-time communications features such as instant messaging (Christakis \& Fowler, 2009).

Our research is situated within emerging research on the 'learner's perspective' on elearning and mobile learning, in the context of increasing learner autonomy, personal choice of tools and learning spaces, and decreasing institutional control. It also contributes to debates engendered by the idea that education must change in response to a new generation of learners. Typically the 'new generation' is understood as comprising those born in the period since the early 1980 s, variously referred to as the Net generation (Tapscott, 1998, 2008), Digital Natives (Prensky, 2001, 2009) and Millennials (Oblinger \& Oblinger, 2005), whose expectations in respect of technology use are claimed to be significantly different from the generations that preceded it. Jones, Ramanau, Cross and Healing (2010) have critiqued the 'new generation' arguments, concluding that "overall there is growing theoretical and empirical evidence that casts doubt on the idea that there is a defined new generation of young people with common characteristics related to their exposure to digital technologies and networked communication throughout their lives" (p. 6). Instead, their research points to the existence of a number of notable 'minorities' within the generation, such as "a large minority who make use of the Internet to download or upload materials and a smaller minority who contribute to blogs and wikis or engage with virtual worlds" (p. 21). Within their sample of First Year university students in the UK, almost all students owned a mobile phone; an mp3-device or other digital music player was commonly owned as well, but the use of these portable devices was not explored in any detail. Conole, de Laat, Dillon and Darby (2008) found that students made use of mobile phones frequently to phone and text each other, particularly when they had assignment queries.

We consider that learners who use handheld mobile devices (e.g., their phones and mp3players) to support their learning constitute a minority at the present time. We agree that their age seems less important than their position as early adopters and instigators of change through their influence among their peers and through their networks. Nevertheless, age has a bearing on behaviour in terms of learners' experience and the ability to reflect on that experience. We decided to focus our investigations on more mature learners, that is, those who are at the point of completing their Higher Education, in particular those studying at master's or doctoral level in 
the fields of education, educational technology, engineering and information technology. Our assumption was that students registered on such programmes would be particularly strong in their capacity to reflect on their learning and to point the way to future practices that others might in time adopt. We wanted to invite them to volunteer their opinions, personal accounts, and information about how they use their mobile devices. A previous survey and interviews have been conducted with this target student population in the United Kingdom, demonstrating that it is possible to collect valuable data (Pettit \& Kukulska-Hulme, 2007; Kukulska-Hulme \& Pettit, 2009).

\section{RESEARCH OBJECTIVES}

In this section we discuss the objectives of our international survey by online questionnaire, which focused on students registered on selected master's and doctoral programmes in Australia, Hong Kong, Portugal, Sweden and the United Kingdom. The sample was purposive, targeting mostly older, 'mature'students, enrolled in study programmes at the authors' home institutions at the time of data collection. Some recent graduates were also invited to participate. The overall aim of the research was to give an account of everyday uses and more unusual deployments of portable technologies by the students, in relation to four areas:

- $\quad$ Learning

- Social interaction

- Entertainment

- Work

The widespread use of information and communication technologies in many contemporary societies means that it is increasingly difficult to draw boundaries between these four activities in people's lives, since there is interplay between them (Kukulska-Hulme \& Pettit, 2009). We wanted to remain open to the possibility that the use of mobile technology in some or all of these areas might help contextualize how the technology is used in learning. We acknowledge that 'learning' is not an unambiguous term; increasingly, online social interaction is an explicit aspect of many courses, and some activity reported under the rubric of 'social interaction' may also relate to learning.

The research sought to identify how various mobile devices are used, on an individual basis and as part of communities, and to uncover emerging practices. The following key research questions guided the study:

- How do mature students make use of different types of mobile device in relation to learning, social interaction, entertainment and work?

- Does mobile device use support mature students in being part of communities and groups?

- Which are the most and least frequent uses of mobile devices?

- What are the perceived innovative aspects and disadvantages of mobile devices in relation to learning?

In addition to capturing accounts of experience, we were interested in gathering data that might challenge the still widespread opinion amongst educators that mobile devices are of little use for academic study. Activities such as web browsing, reading e-news, article reading, book reading and note taking are valued in the academic world but often considered implausible on handheld devices. Furthermore, we were interested in how mobile devices support informal and community learning. In short, we set out to investigate learner-driven practice with mobile technologies, any innovation arising from that practice, and the interface between formal and informal learning. The survey is a step forward in what is a long-term research commitment to understanding and interpreting evolving practice in learner-driven mobile learning.

The fast-changing technological landscape means that the interpretation of what counts as a 'mobile device' is constantly changing. 
The survey specified that we were not asking about the use of tablets and laptops. Since the survey was developed, other devices including notebook computers and ebook readers have become popular, making it even more difficult to draw boundaries between 'handheld learning', 'laptop learning' and 'desktop learning'. Our survey avoided confusion by asking questions about use of specific types of device, giving examples where it was deemed necessary (e.g. "Have you used a PDA, e.g. Palm, HP iPAQ, iPod Touch?").

Our research is concerned with mature students' experiences in the five countries where the survey was conducted; furthermore, we are able to highlight some differences that became apparent, which will enable educators to have more informed conversations with their students about their mobile learning practices, and will enable researchers to design further investigations of those apparent differences. We have used our own contextual knowledge as researchers living in these countries to assist with interpretation; in that sense, our research is international and local. The survey findings were therefore enriched by local knowledge of social, economic or political factors which may have an impact on user choices.

The value of this research is expressed not only in the actual findings but additionally in that the findings constitute a good basis for conversations that can ensue between educators and learners. Students do not always realise the potential of new tools and this is an aspect where educators can help (Trinder, Guiller, Margaryan, Littlejohn \& Nicol, 2008). Furthermore, given today's global education marketplace, it is necessary for educators to get to know the expectations of their international students, as distinct from their domestic cohort. Knowing something about their previous practices with mobile devices and the techno-cultural setting they come from, can help determine the most appropriate use of mobile technology.

The paper first presents some background information about the target students and their localities. This is followed by details of the questionnaire and our research findings. Finally, we discuss the findings and offer some reflections and conclusions.

\section{PARTICIPANTS}

The target student groups in Australia, Portugal, Sweden, Hong Kong and the United Kingdom were given information about the research and invited to complete the online questionnaire in their own time on a voluntary basis. Responses were anonymous, but respondents could provide their name and email address if they were willing to be contacted for follow-up research.

\section{Australia}

Participants were from the University of Wollongong, a regional Australian university. The mobile learning questionnaire targeted students enrolled in the one-year Masters by coursework degree in specialist areas which include: Adult Education, Higher Education and Vocational Education; Educational Leadership; Information and Communication Technologies in Education and Training; Language and Literacy; Physical and Health Education; Special Education; and Teaching English to Speakers of Other Languages. Most students in the programme were Australian citizens (76\%) with the remaining coming from 17 countries including Canada, PR China, Saudi Arabia, New Zealand, UK, India, Japan, Malaysia, Indonesia, and USA. Educational leadership was the most popular major studied (25\%) followed by Adult Education (11\%) and Language and Literacy (10\%). The students came from a wide range of educational professions predominantly teachers and trainers from across the school and tertiary sectors.

\section{Portugal}

Participants from the University of Minho, Portugal, were registered students on the university's Masters in Education (Educational Technology), a programme developed by the 
Department of Curriculum and Educational Technology, at the Institute of Education and Psychology. Students on this programme are typically experienced practitioners working in the education sector, mainly teachers; most of the students are Portuguese but some are Brazilians. All participated in face-to-face sessions weekly. A virtual learning environment was used to access materials and sometimes to engage in discussion or group work. Podcasts were used to give students feedback about their assignments or group presentation.

\section{Sweden}

The participants were master's students in Computer Science and Mechanical Engineering at Chalmers University of Technology, Gothenburg, within programmes such as software engineering, interaction design, applied mechanics and production development. There are only campus-based courses at Chalmers and no distance based ones. However, in 2008, 547 Masters students out of 1523 were international students. Higher education in Sweden is free of charge (although this may change in the future), which is a contributing factor to the high number of students from abroad. Also, the requirement that master's courses should be taught in English means that many international students choose Sweden.

\section{Hong Kong}

Participants from Hong Kong University were a mixture of full and part-time Masters of Science students (Information Technology in Education), a programme that had been running successfully for more than five years. The majority of students in this programme are primary or secondary teachers, however, the diversity of intake had broadened considerably to include individuals that work in publishing, banking and adult education training environments. The programme of study is undertaken in blended mode with face-to-face and online classes. Students enjoy free wireless access at the university and in numerous public locations around Hong Kong.

\section{United Kingdom 1}

The Leeds University group consisted of postgraduate students. The participants were all studying on MA programmes in Education, so the majority of them were teachers or lecturers, with a few other education professionals such as librarians and people working in educational management. Participants were not asked to identify their programme of study but from the 22 who gave their names, 13 were on the MA ICT in Education. Of these, 9 were distance students. The materials for some modules on the MA ICT in Education include podcasts which students may listen to online/on computer or may download to mobile devices -- although Walker(2009) shows that relatively few students transfer the podcasts to mobile mp3 players. At the time of this study, none of the other MA programmes at Leeds included podcasts or other materials intended for use on mobiles.

\section{United Kingdom 2}

Participants from The Open University were registered students and alumni of the university's Masters in Online and Distance Education (MAODE), a global-intake programme developed by the Institute of Educational Technology. Students and alumni of this programme are typically experienced practitioners working in the education sector; some are British nationals temporarily working overseas. All participate in the programme through online distance education, using a virtual learning environment to access materials and engage in discussion or group work. There is no requirement for them to meet face-to-face. Some of the students/alumni in this group are likely to have been involved in an MAODE special project in which they were given a PDA to use for learning during 2001.

\section{INTERNATIONAL SURVEY}

The International Survey was conducted between May 2008 and April 2009 by means of an extensive online questionnaire (see Appendix), adapted from one used previously for our study 
in 2005 (Kukulska-Hulme \& Pettit, 2006,2009). The questionnaire comprised a mix of closed and open questions in five sections. It enabled the capture of qualitative and quantitative data on the use of various mobile devices in diverse spheres of activity; the workings of communities and groups; frequency of specific actions; and reflections on benefits and disadvantages:

Section 1. About yourself

- Respondents gave information about their age, gender, country where they spend most/all of their time, and job/profession.

Section 2. The use of mobile devices - now or in the past

- For each device used (mobile phone, smartphone, PDA, mp3/ mp4 player), respondents were asked to "give one or more examples in detail" to show how they used it for learning, for social interaction, for entertainment/quizzes/games, and for work/teaching (note: many target students and alumni worked in teaching).

Section 3. Being part of groups and communities

- The questionnaire explained that groups/ communities could be formal or informal. Respondents were asked to describe the purposes of the groups they are part of, which devices they used, the benefits of being part of the group and to say whether they could be in this group if they did not use a mobile device.

Section 4. Specific uses for mobile devices

- Twenty-seven specific uses were listed (browsing websites, reading an e-book, listening to podcasts, taking photos, etc.). For each use, frequency had to be selected from 7 possible responses ranging from 'several times a day' to 'never'.
Section 5. Mobile devices for learning: what's special, what's a problem?

- Respondents were asked to say what they consider to be new and innovative about their use of mobile devices for learning, and what is the single biggest problem or disadvantage that mobile devices bring them in relation to their learning.

The open questions enabled participants to write a response in their own terms. These questions were included so as to avoid the limitations of pre-set categories of response when the main objective was to capture accounts of experience that could be said to constitute "sitespecific case studies" where rich and personal data is of prime importance (Cohen, Manion \& Morrison, 2000, pp. 247-248). A constraint was that respondents were requested to write in English; judging from their responses, this was not a problem for the majority, but we cannot rule out some difficulty in self-expression.

Student participation in the research was voluntary and unconnected to study progress or assessment. A total of 270 students completed the questionnaire. Response rates were not recorded, as our research was deliberately based on volunteer samples. With the exception of Sweden, there were larger numbers of female respondents (Table 1). The students surveyed in Sweden were from programmes where there are large numbers of male students.

Whilst our survey was deployed in five different countries, the students who responded sometimes indicated that they spent "most or all of their time" in another country. The Australian group included 4 students from Japan and 11 from other countries; the Hong Kong group had 5 students from China and one from the US; the group from Sweden included 9 spending most or all of their time outside Sweden. Over half of the UK (Leeds University) group were from outside the UK, and nearly half of the UK (Open University) group were from outside the UK (one person did not reply to this question). Only the students in 
Table 1. Respondents to the survey

\begin{tabular}{|c|c|c|c|c|c|}
\hline $\begin{array}{l}\text { Country where survey } \\
\text { was administered }\end{array}$ & Responses & $\begin{array}{l}\text { \% respondents } \\
\text { from other } \\
\text { countries* }\end{array}$ & $\begin{array}{l}\text { Age range of } \\
\text { respondents* }\end{array}$ & Female & Male \\
\hline Australia & 67 & $22 \%$ & $\begin{array}{c}3 \%<25 \\
33 \% 25-34 \\
27 \% 35-44 \\
30 \% 45-54 \\
7 \% 55-64\end{array}$ & $78 \%$ & $22 \%$ \\
\hline Hong Kong & 23 & $26 \%$ & $\begin{array}{c}9 \%<25 \\
57 \% 25-34 \\
35 \% 35-44\end{array}$ & $70 \%$ & $30 \%$ \\
\hline Portugal & 28 & $0 \%$ & $\begin{array}{c}61 \% 25-34 \\
32 \% 35-44 \\
7 \% 45-54\end{array}$ & $64 \%$ & $36 \%$ \\
\hline Sweden & 66 & $14 \%$ & $\begin{array}{c}48 \%<25 \\
44 \% 25-34 \\
6 \% 35-44 \\
2 \% 45-54\end{array}$ & $20 \%$ & $80 \%$ \\
\hline UK (Leeds University) & 38 & $53 \%$ & $\begin{array}{c}11 \%<25 \\
39 \% 25-34 \\
34 \% 35-44 \\
16 \% 45-54\end{array}$ & $68 \%$ & $32 \%$ \\
\hline UK (The Open University) & 48 & $45 \%$ & $\begin{array}{c}4 \% 25-34 \\
34 \% 35-44 \\
42 \% 45-54 \\
19 \% 55-64 \\
2 \% 65 \text { and over }\end{array}$ & $54 \%$ & $46 \%$ \\
\hline TOTAL & 270 & & & & \\
\hline
\end{tabular}

* Percentages have been rounded

Portugal spent most or all of their time in that country. We note that these student profiles reflect the increasingly international mix among those studying at master's and doctoral levels globally. We recognize there may be a number of factors influencing mobile device use, including age of respondents, gender, nature of the program being studied, infrastructure and tariffs in the country concerned, and cultural practices.

Data from each of the five participating countries were stored in separate databases. The quantitative data were subjected to a descriptive statistical analysis, whilst the qualitative data were analyzed manually for each question in the survey, enabling us to examine use examples in detail. We extracted actual examples of use (see Table 3) and noted prominent cases where similar uses were mentioned by more than one respondent.

\section{SURVEY FINDINGS}

Presented below are salient findings from the survey, concentrating on characterizations of how various devices are used, what respondents say about the use of mobile devices as part of a group or community, key findings regarding specific uses, and finally, respondents' comments about positive and negative aspects of using mobile devices for learning. 


\section{How Mobile Devices Are Used}

The questionnaire included a section on the use of mobile devices - now or in the past - where for each device used, respondents were asked to provide one or more examples. The data enabled us to answer the first research question: How do mature students make use of different types of mobile device in connection with learning, social interaction, entertainment and work?

First, we note that as could be expected, mobile phone use is shown to be near-universal, although there is minor variation across the groups (Table 2). The use of mp3 and mp4players is also predictably high; the figures for use of smartphones and PDAs vary considerably across the groups.

The questionnaire data contains a rich array of 'use examples' for each of the four devices specified, under each of the four categories that respondents were asked to write about. If we set aside the most obvious examples, such as using the mobile phone to make calls or an mp3 player to listen to music, there is an abundance of use examples that illustrate the versatility of each device in the ways it can support a broad range of activity. Examples of reported mobile phone and smartphone uses across four categories are presented in Table 3, selected to show a broad range of uses (the examples are quoted verbatim). Overall we note that:

- There are receptive, productive and communicative uses
- Respondents are using mobile devices to capture ideas and experiences

- Mobile devices have a useful function as tools that remind the user about what she/ he has to do

- Respondents make use of a range of applications for informal learning

- One function of games is to fill gaps in the day

- $\quad$ Some respondents appear to be drawing boundaries around disparate uses

- The mobile phone features as an alternative means of communication and to support physical mobility, e.g. as an alternative to having a land line or when work involves travelling

Overall in the 'learning' category of examples, the most prominent uses are contact with others, immediate access to information and answers, reading e-books, listening to podcasts, and scheduling. More unusual uses mentioned include creating an educational resource; use of vodcasts of educational and documentary TV shows; recording one's voice in preparing a presentation; recording something on an iPhone and replaying it on an iPod; taking photos of billboard advertisements and pictures in reference books; contacting experts in other fields; uploading notes to a blog. Facebook, Windows Live Messenger, MSN and Skype receive several mentions. Language learning is also a popular activity amongst respondents.

Table 2. Devices used

\begin{tabular}{|c|c|c|c|c|}
\hline & mobile phone & smartphone & PDA & mp3/mp4-player \\
\hline Australia & $91 \%$ & $22 \%$ & $15 \%$ & $75 \%$ \\
\hline Hong Kong & $78 \%$ & $35 \%$ & $22 \%$ & $65 \%$ \\
\hline Portugal & $86 \%$ & $7 \%$ & $7 \%$ & $74 \%$ \\
\hline Sweden & $97 \%$ & $11 \%$ & $14 \%$ & $80 \%$ \\
\hline UK - Leeds & $100 \%$ & $19 \%$ & $22 \%$ & $62 \%$ \\
\hline UK - OU & $94 \%$ & $25 \%$ & $46 \% *$ & $71 \%$ \\
\hline
\end{tabular}

* Includes students from the special project with PDAs, which may explain this relatively high percentage. 
Table 3. Examples of mobile phone/ smartphone use, for four categories of activity

\begin{tabular}{|c|c|c|c|c|}
\hline & ...for learning & $\begin{array}{c}\text {... for social inter- } \\
\text { action }\end{array}$ & $\begin{array}{c}\text {... for entertain- } \\
\text { ment/ } \\
\text { quizzes/games }\end{array}$ & $\begin{array}{c}\text {... for work/teach- } \\
\text { ing }\end{array}$ \\
\hline Australia & $\begin{array}{l}\text { Have the Bureau of } \\
\text { Metereology as an } \\
\text { application on the } \\
\text { phone to check weather } \\
\text { systems and fronts. }\end{array}$ & $\begin{array}{l}\text { To contact friends } \\
\text { and family as we do } \\
\text { not have a land line, } \\
\text { so all calls are on } \\
\text { my mobile. }\end{array}$ & $\begin{array}{l}\text { Play games, use } \\
\text { iphone applications } \\
\text { - yahtzee, dice } \\
\text { games etc., music } \\
\text { and audio books }\end{array}$ & $\begin{array}{l}\text { As majority of } \\
\text { my work involves } \\
\text { being on the road, } \\
\text { used as a communi- } \\
\text { cation tool. }\end{array}$ \\
\hline Hong Kong & $\begin{array}{l}\text { Use the dictionary to } \\
\text { learn English. } \\
\text { Get the group members } \\
\text { together to prepare for } \\
\text { the presentation. }\end{array}$ & $\begin{array}{l}\text { Calls, messages, } \\
\text { sending images. } \\
\text { Check friends on } \\
\text { Facebook. } \\
\text { Windows Live } \\
\text { Messenger. }\end{array}$ & $\begin{array}{l}\text { May take photo or } \\
\text { video all the time } \\
\text { if you got a big } \\
\text { memory card. } \\
\text { Reading novels. } \\
\text { Watch YouTube } \\
\text { videos. }\end{array}$ & $\begin{array}{l}\text { Mark down impor- } \\
\text { tant points when } \\
\text { came to mind. } \\
\text { Take photos for } \\
\text { records of site } \\
\text { inspection. }\end{array}$ \\
\hline Portugal & $\begin{array}{l}\text { To interact with my } \\
\text { group mates. } \\
\text { To take photos. } \\
\text { To know some events } \\
\text { that are going to hap- } \\
\text { pen. }\end{array}$ & $\begin{array}{l}\text { Sms and call to } \\
\text { friends, and sms to } \\
\text { a micro blog web } \\
\text { site (Twitter). } \\
\text { As a camera video } \\
\text { and as a tom tom. }\end{array}$ & $\begin{array}{l}\text { Sometimes I enter } \\
\text { some contests and } \\
\text { therefore use my } \\
\text { mobile to answer } \\
\text { the quizzes. }\end{array}$ & $\begin{array}{l}\text { My students listen } \\
\text { [to] podcasts in } \\
\text { their cellphones, } \\
\text { take pictures and } \\
\text { make films for } \\
\text { discussion... }\end{array}$ \\
\hline Sweden & $\begin{array}{l}\text { I use the calendar to } \\
\text { structure my studies. } \\
\text { Adding reminders to } \\
\text { myself. } \\
\text { Listen to educative } \\
\text { radio shows. }\end{array}$ & $\begin{array}{l}\text { To call abroad using } \\
\text { Skype out number. } \\
\text { Videophone calls to } \\
\text { friends, family and } \\
\text { work mates. }\end{array}$ & $\begin{array}{l}\text { Reading news on } \\
\text { internet. } \\
\text { Built-in games on } \\
\text { my phone, but got } \\
\text { bored quite soon. }\end{array}$ & $\begin{array}{l}\text { Help me remember } \\
\text { stuff that I'm sup- } \\
\text { posed to do. } \\
\text { Sometimes I buy } \\
\text { bus tickets with the } \\
\text { mobile. }\end{array}$ \\
\hline UK - Leeds & $\begin{array}{l}\text { I have used the recorder } \\
\text { to record memos to my- } \\
\text { self when I have ideas } \\
\text { for research, essays } \\
\text { etc. Translating from } \\
\text { English into Arabic. }\end{array}$ & $\begin{array}{l}\text { To call friends to } \\
\text { arrange a meeting, } \\
\text { but not to 'talk } \\
\text { about life'. } \\
\text { To plan things. }\end{array}$ & $\begin{array}{l}\text { Sometimes when } \\
\text { I'm waiting for an } \\
\text { appointment, I tend } \\
\text { to use the phone to } \\
\text { play. }\end{array}$ & $\begin{array}{l}\text { Video camera for } \\
\text { recording and tak- } \\
\text { ing photos which } \\
\text { I later transferred } \\
\text { into my computer to } \\
\text { use as a teacher. }\end{array}$ \\
\hline UK - OU & $\begin{array}{l}\text { Kanji a day - learning } \\
\text { Japanese and Chinese } \\
\text { characters. } \\
\text { I have used it to read the } \\
\text { news. } \\
\text { Listening to the radio. }\end{array}$ & $\begin{array}{l}\text { I send texts and } \\
\text { pictures to family } \\
\text { and to the Moblog } \\
\text { community. } \\
\text { Taking photos and } \\
\text { videos spontane- } \\
\text { ously. }\end{array}$ & $\begin{array}{l}\text { Exchanging funny } \\
\text { videos with friends. } \\
\text { Discussion forums } \\
\text { and sharing links. }\end{array}$ & $\begin{array}{c}\text { Make records of } \\
\text { worthwhile experi- } \\
\text { ences. } \\
\text { This is a personal } \\
\text { device and I keep } \\
\text { it entirely separate } \\
\text { from my work. }\end{array}$ \\
\hline
\end{tabular}

'Social interaction' examples contain references to keeping in contact with friends and family who are nearby or dispersed around the globe. Finding information, accessing sites such as YouTube, sending images, sharing playlists and exchanging music files with others are also reported, as well as contact during project work. Headphones attached to a mobile device are used to cut out unwanted social interaction during commuting or at work; dual headphones are used to listen together with others. Several respondents mention restricting their social use to contact with family and friends. Social interaction includes handing over your device to a friend so that they can browse through your pictures at their own pace.

The 'entertainment/quizzes/games'category shows productive activities such as making 
videos and taking photos, alongside listening, watching, reading and playing. 'Pre-installed' and 'default' games are often mentioned. Within 'work/teaching', mobile device use includes appointments, reminders, use in emergencies and on trips, as props in class, and to provide entertainment or materials for classes; there is also contact with students to offer tutoring or to discuss assessments. The quantity of data in all four categories precludes us from being able to list all reported uses.

\section{The Use of Mobile Devices as Part of a Group or Community}

The middle section of the questionnaire was designed to find out whether mobile device use supports respondents in being part of communities and groups, both formal and informal. It was explained that these communities and groups could relate "to friends, leisure, family, study, work, etc". If respondents stated that they use a mobile device to be part of one or more groups or communities (see Table 4), they were invited to give some details of their activities, which devices they used, and how they had benefitted from being part of the community/group. As seen in Table 4, there is considerable variation between the groups of respondents with regard to their reported use of mobile devices to be part of a community or group.

Apart from communication among family and friends, respondents refer to leisure and voluntary pursuits and keeping in touch with former colleagues by using mobile devices. The mobile phone/SMS and group texts, Skype, MSN, video meetings, GPS and micro blogging are key technologies. Tablets and laptops are mentioned in passing (even though they were supposed to be excluded from the survey), which possibly suggests that handheld devices may not always suffice. Social networking communities such as Facebook and identica.ca (a micro blogging community) are named in addition to traditional communities and friendship groups.

SMS plays an important role in alerting members of groups and communities and as a connection point between other technologies. For example, SMS is used to alert community members about an important email message which they might otherwise not see; Pager messages on the phone via SMS alert a volunteer that they are needed by their community; Members of a paragliding club report weather conditions via SMS to a central number and all members get the message forwarded on to them; A mobile phone is used by a teacher to redirect students to course-related resources.

Reported benefits of using mobile devices to be part of groups or communities include spontaneous communication, flexibility, speed, fun, support, experience sharing, intellectual stimulation and use of technology to cope with changing arrangements. The data from the UKOU group are particularly rich in this regard; by contrast, the Hong Kong, Portugal and Sweden respondents were largely silent here.

Table 4. Responses to the question, "Do you use a mobile device to be part of one or more groups or communities?"*

\begin{tabular}{|c|c|c|}
\hline & No & Yes \\
\hline Australia & $61 \%$ & $39 \%$ \\
\hline Hong Kong & $87 \%$ & $13 \%$ \\
\hline Portugal & $86 \%$ & $14 \%$ \\
\hline Sweden & $81 \%$ & $19 \%$ \\
\hline UK - Leeds & $70 \%$ & $30 \%$ \\
\hline UK - OU & $47 \%$ & $53 \%$ \\
\hline
\end{tabular}

* Percentages have been rounded 


\section{Key Findings on Specific Uses for Mobile Devices}

This section of the questionnaire was designed to elicit information about 27 distinct uses of mobile devices. This was a broad repertoire of possible uses, based on typical functionality of mobile devices such as web browser, video, camera, GPS, etc. (Trinder, 2005), and elaborated by the project team to include emerging activities such as video-sharing, micro-blogging and using location-based services. Respondents could also add other uses which were not listed. The aim was to find out which were the most and least frequent uses. We were also interested to identify the 'most intensive' uses, meaning that an activity was performed several times a day, as distinct from just once or twice a day. A subsidiary aim was to discover the extent to which respondents were using mobile devices for more academic activities such as reading academic papers or recording a seminar. The presented uses covered:

- Browsing, reading, viewing, listening;

- Accessing information and doing searches;

- Making and recording;

- Sharing (sending and posting);

- Playing a location-based game

This range is typical in taxonomies representing activities or tasks: assimilative, information handling, productive, communicative and experiential (e.g. used by Conole, 2007, who also includes 'adaptive' activity such as modelling or simulation). Uses that had some similarity were listed one after the other (e.g. reading an e-book, reading e-news, reading an academic paper; listening to music, listening to podcasts). Several were fairly specific, e.g. 'Sending a video clip from your mobile device to a video-sharing site'. Participants were asked to respond to each of the 27 uses, irrespective of mobile device employed, indicating the frequency of use on a 7-point scale (several times a day; once or twice a day; a few days a week; once a week; once a month; less than once a month; never).

The three most and least frequent uses, reported by each country, are shown in Tables 5 and 6 . Table 5 distinguishes between 'most intensive uses' (defined as: several times a day) and 'most frequent uses' (once a week or more, i.e., an aggregation of the first four points on the scale, including several times a day).

The three most intensive uses are very clearly sending text messages, browsing websites and listening to music; reading e-news also makes an appearance (see Table 5). When it comes to the most frequent, but less intense uses, browsing websites is supplanted by taking photographs and using a mobile device to make notes. In the UK-OU group, $40 \%$ of respondents report listening to podcasts. (The relevant percentage for UK-Leeds is $39 \%$, whereas it is considerably lower in Portugal 26\%, Australia $26 \%$, Hong Kong $22 \%$, and Sweden $9 \%$; however, it should be noted that we know some tutors provided podcasts as part of their study materials).

Least frequent uses are those where the highest proportions of responses were 'never'; the responses here show that playing a locationbased game was very infrequent, along with posting to a micro-blog, posting to your blog from your mobile device, sending a video clip from your mobile device to a video-sharing site, and (for the Hong Kong respondents) recording a formal interview.

Table 7 shows the frequency of reading e-books and academic papers. Respondents from Hong Kong report the highest frequency in relation to both uses. Along with reading books and papers, academic study may also involve doing interviews as part of research and attending seminars and presentations; frequencies of 'recording a formal interview e.g., as part of your research', and 'recording a seminar or other presentation by a speaker', were very low across all groups $(0-6 \%$ reporting once a week or more). 
Table 5. The most intensive and the most frequent uses*

\begin{tabular}{|c|c|c|c|c|}
\hline & $\begin{array}{l}\text { Most intensive uses } \\
\text { (several times a day) }\end{array}$ & $\%$ & $\begin{array}{l}\text { Most frequent uses } \\
\text { (once a week or more) }\end{array}$ & $\%$ \\
\hline Australia & $\begin{array}{l}\text { 1. Sending text-messages (SMS) } \\
\text { 2. Browsing websites } \\
\text { 3. Listening to music }\end{array}$ & $\begin{array}{l}33 \% \\
15 \% \\
12 \%\end{array}$ & $\begin{array}{l}\text { 1. Sending text-messages (SMS) } \\
\text { 2. Listening to music } \\
\text { 3. Browsing websites }\end{array}$ & $\begin{array}{l}91 \% \\
58 \% \\
32 \%\end{array}$ \\
\hline Hong Kong & $\begin{array}{l}\text { 1. Sending text-messages (SMS) } \\
\text { 2. Browsing websites } \\
=2 . \text { Listening to music } \\
\text { 4. Reading e-news }\end{array}$ & $\begin{array}{l}30 \% \\
26 \% \\
26 \% \\
22 \%\end{array}$ & $\begin{array}{l}\text { 1. Sending text-messages (SMS) } \\
\text { 2. Taking a photograph } \\
\text { 3. Listening to music }\end{array}$ & $\begin{array}{l}74 \% \\
61 \% \\
57 \%\end{array}$ \\
\hline Portugal & $\begin{array}{l}\text { 1. Sending text-messages (SMS) } \\
\text { 2. Browsing websites } \\
\text { 3. [five uses come joint third]** }\end{array}$ & $\begin{array}{l}61 \% \\
18 \% \\
11 \%\end{array}$ & $\begin{array}{l}\text { 1. Sending text-messages (SMS) } \\
\text { 2. Using a mobile device to make notes } \\
\text { 3. Taking a photograph }\end{array}$ & $\begin{array}{c}100 \% \\
75 \% \\
68 \%\end{array}$ \\
\hline Sweden & $\begin{array}{l}\text { 1. Sending text-messages (SMS) } \\
\text { 2. Listening to music } \\
\text { 3. Browsing websites }\end{array}$ & $\begin{array}{l}32 \% \\
15 \% \\
11 \%\end{array}$ & $\begin{array}{l}\text { 1. Sending text-messages (SMS) } \\
\text { 2. Listening to music } \\
\text { 3. Taking a photograph }\end{array}$ & $\begin{array}{l}92 \% \\
62 \% \\
40 \%\end{array}$ \\
\hline $\begin{array}{c}\text { UK } \\
\text { Leeds }\end{array}$ & $\begin{array}{l}\text { 1. Sending text-messages (SMS) } \\
\text { 2. Listening to music } \\
\text { 3. Browsing websites }\end{array}$ & $\begin{array}{l}65 \% \\
18 \% \\
16 \%\end{array}$ & $\begin{array}{l}\text { 1. Sending text-messages (SMS) } \\
\text { 2. Listening to music } \\
\text { 3. Using a mobile device to make notes }\end{array}$ & $\begin{array}{l}97 \% \\
61 \% \\
55 \%\end{array}$ \\
\hline $\begin{array}{l}\text { UK } \\
\text { OU }\end{array}$ & $\begin{array}{l}\text { 1. Sending text-messages (SMS) } \\
\text { 2. Browsing websites } \\
=2 . \text { Listening to music } \\
\text { 4. Reading e-news }\end{array}$ & $\begin{array}{l}29 \% \\
13 \% \\
13 \% \\
6 \%\end{array}$ & $\begin{array}{l}\text { 1. Sending text-messages (SMS) } \\
\text { 2. Listening to music } \\
\text { 3. Listening to podcasts }\end{array}$ & $\begin{array}{l}67 \% \\
54 \% \\
40 \%\end{array}$ \\
\hline
\end{tabular}

* Percentages have been rounded

** Joint third: Listening to music, Reading e-news, Taking a photograph, Using a mobile device to make notes, Using Google or another search engine.

Table 6. The least frequent uses*

\begin{tabular}{|c|c|c|c|c|c|c|}
\hline $\begin{array}{c}\text { Least frequent uses } \\
\text { (never) }\end{array}$ & Aust & HK & Port & Swed & UK-L & UK-OU \\
\hline Playing a location-based game & $97 \%$ & & $86 \%$ & $97 \%$ & $97 \%$ & $94 \%$ \\
\hline Posting to a micro-blog & $95 \%$ & $91 \%$ & $96 \%$ & $97 \%$ & $95 \%$ & $89 \%$ \\
\hline $\begin{array}{c}\text { Posting to your blog from your mobile } \\
\text { device }\end{array}$ & $91 \%$ & $83 \%$ & $89 \%$ & $95 \%$ & $94 \%$ & $87 \%$ \\
\hline $\begin{array}{c}\text { Sending a video clip from your mobile } \\
\text { device to a video-sharing site }\end{array}$ & & & & $95 \%$ & & \\
\hline Recording a formal interview & & $78 \%$ & & & & \\
\hline
\end{tabular}

* Percentages have been rounded

\section{Positive and Negative Aspects of Using Mobile Devices for Learning}

Respondents were asked to write in their own words what they consider to be new and innovative about their experience of using mobile devices for learning. Responses included well established advantages such as convenient access to information or to the Internet and the ability to contact people whenever needed. Specific new/innovative aspects noted by respondents included the following: 
Table 7. Frequency of reading e-books and academic papers*

\begin{tabular}{|c|c|c|c|c|c|c|}
\hline $\boldsymbol{e}$-books & Australia & Hong Kong & Portugal & Sweden & UK Leeds & UK OU \\
\hline Once a week or more & $9 \%$ & $43 \%$ & $19 \%$ & $8 \%$ & $11 \%$ & $10 \%$ \\
\hline Academic papers & Australia & Hong Kong & Portugal & Sweden & UK Leeds & UK OU \\
\hline Once a week or more & $12 \%$ & $35 \%$ & $25 \%$ & $11 \%$ & $24 \%$ & $21 \%$ \\
\hline
\end{tabular}

* Percentages have been rounded

- Permanency of taking notes; paper is easily lost

- Multipurpose; you can take your work/ entertainment with you

- Can combine a walk or run with listening to a podcast

- Podcasts give access to unique historical/ scientific content

- Suits auditory learners

- Closer relationship between students and teacher

- Multimedia in one small device is a timesaver for teachers

- Instant documentation of whiteboard notes

- Taking photos of overhead slides

- Help with learning disabilities

- Alternative news source/ breaking news / immediate first hand reports

- Helps maintain a public diary with a community dimension

- Quick way to learn

- Gets you outdoors

- Field trips become more fruitful and challenging

There were also a few responses indicating that nothing was new ('same material, different format'). A further question asked about problems and disadvantages. Apart from expected answers such as small screen size and issues of cost, which we do not report here, respondents mentioned various ergonomic, technical and social issues:

- Slow writing, difficulty scanning when reading

- Noisy environments, e.g. on public transport
- Restrictive environments, e.g. hospitals

- Can't connect mobile to projector

- Difficulty synchronizing several devices

- Poor sound quality

- Inequality of access

- Distracting, intrusive

- Feeling of 'physical togetherness' is missing

- Becoming dependent on the mobile

\section{DISCUSSION AND REFLECTIONS}

The study has delivered interesting first results into emerging use cases of mobile devices which can serve as a link to foster learning in formal and informal contexts. Mobile devices are shown to support informal and community learning. There are numerous reported benefits, particularly emphasized by the distance education students (UK-The Open University). While the predominant use for mobile devices is communication, it seems that other aspects of social interaction can benefit, such as the ability to share media between mobile devices directly or blended across other social networking technologies like Facebook.

Amongst the mature age students surveyed, receptive, productive and communicative uses are in evidence across learning, social, entertainment and workplace environments. The research confirms the global popularity of SMS, browsing websites, listening to music, taking photographs and making notes. It also highlights that reading e-news and listening to podcasts are relatively frequent activities among some students, and that article- and book-reading, once considered implausible on handheld devices, are popular among a minority. 
Using mobile devices for entertainment and in the workplace highlights the importance of these technologies for users who themselves are mobile. Making productive use of downtime while travelling and keeping in contact with work colleagues has become part of daily life even though some clearly wish to retain a distinct work-life boundary. These activities are further enabled by the increasing availability of WiFi on different modes of commuter transport. The research provides good evidence of a contrast between claims that mobile learning can take place 'anytime, anywhere' and reported practice which often describes irregular usage dependent on a range of factors.

The data continue to show the main use for these devices involves communication through phone and text, and referencing information such as websites, readings and maps. What is interesting is that there appear to be many ways in which users are employing the technologies to generate products. Bruns (2005) coined the term 'produsers' to denote both of these approaches. Our survey shows that mobile devices are enabling users to create resources for teaching purposes, write blogs to keep their friends up to date with events, take and distribute photos and videos, and make and take notes and recordings.

Uses within specific countries suggest evolving social and cultural practices that may result from patterns of use among friends, family, colleagues and teachers. This research helps to identify uses of mobile devices that teachers and others can exploit to further unlock the potential for using these devices as cognitive tools to support learning (Herrington et al., 2009). By considering apparent differences between learner practices in different countries, we enable researchers and teachers to become more sensitive to different circumstances facing students who are studying remotely or spending time away from their usual place of study, and can help educational practitioners designing learning for culturally diverse cohorts. As noted earlier, the student profiles in our survey reflect the increasingly international mix among those studying at master's and doctoral levels.
We did not attempt to identify purely 'native' mature student samples and it can be argued that it would be futile and misrepresentative to do so, particularly in the programmes of study we were targeting. However a future large-scale and more comprehensive survey could attempt to make such distinctions.

Knowledge of national contexts in terms of technology proliferation, costs of connectivity or cultural imperatives can help to explain learner choices and behaviours (Katz \& Aakhus, 2002). Thus the fact that in Hong Kong there are 11.5 million subscribers in a population of seven million people (OFTA, 2009), and there is free wireless access for students in many public locations in the city, can be regarded as helpful background knowledge. There has been an agreement developed between the major telecommunications player in Hong Kong (PCCW) and universities to provide free wireless access in over 7,900 wireless hotspots, and over 4700 registered Wi-Fi zones in public locations around Hong Kong. These locations include all universities, McDonald's, Starbucks, Pacific Place coffee shops and numerous other venues, including local ferry services. There is cheap internet access; bandwidth is inexpensive and $3 \mathrm{G}$ cards for notebook computers are becoming very common. Cost of access is therefore not likely to be seen as a problem. Similarly, in Sweden there is strong competition between mobile phone operators and the cost of buying a mobile phone, calling and texting is dropping. According to a report from the International Telecommunication Union (ITU, 2009), Sweden is among those countries that offer the most affordable ICT services globally. Contextualization of survey findings is an important challenge for future studies of mobile technology use especially if they are to be done on a large scale and involve many countries.

Looking back at our earlier studies in the UK (Pettit \& Kukulska-Hulme, 2007; Kukulska-Hulme \& Pettit, 2009), we notice that the present data shows a number of new practices among respondents, such as: 
- Using 'apps' on the phone, including Facebook and MSN

- Using GPS to find places

- Watching movies, TV shows, vodcasts

- Listening to audio books, podcasts

- Being part of microblogging communities, e.g., Twitter

- Browsing websites

- Using location-based services, e.g. to find nearby taxis, banks, restaurants, etc.

- No longer having a land line

Current respondents also report feeling that paper is 'easily lost' and less reliable. Mobile device use is a fast-changing field that reflects rapid social changes as well as the increasing availability and smarter marketing of new devices. Anecdotally, our current respondents' "least frequent uses" reported in Table 6-such as playing a location-based game, posting to a blog or micro-blog, and sending a video clip to a video-sharing site - are becoming more widespread, and we would expect these uses to figure more prominently in the future. On the other hand, several usability issues, especially difficulties interacting with a small screen, are still being reported.

In the time since this study was conducted smartphones have become cheaper and more common amongst students and a new generation of 'slate' devices (e.g. Apple iPad TM) has come onto the market. References to Facebook, Skype, or microblogging in the data suggest that the device students are using qualifies as a smartphone. While there are no clear figures available from the data, it may be expected that the use of smart phones will increase as the market becomes dominated by these devices (see Gartner, 2010, who state that worldwide mobile phone sales grew 17 per cent in first quarter of 2010 and that smartphone sales in the first quarter of 2010 represent an increase of 48.7 per cent from the first quarter of 2009.) Several universities now offer 'apps' for smartphones using platforms such as Campus M (http:// www.ombiel.com/campusm.html). Whilst mobile applications are fashionable they are not necessarily cheap and it is important that educators planning to develop apps understand how students perceive and use their mobile devices. Our findings indicate that institutions planning to offer mobile apps should build on the existing preferences of students for social communication, listening to audio, watching videos and reading short texts if the apps are successfully to enhance the learning experience.

It is interesting to compare our findings to those of Walls et al. (2010) who questioned the assumption that students are enthusiastic users of podcasts in their non-university lives and therefore keen for their university to start using them. They found that most students did not even know that podcasts existed but once the tutors started to offer podcasts then some students started subscribing to podcasts more widely. Unlike the Walls et al. study cohort, some of our students were already being provided with podcasts so that could account for the difference in the findings. However our findings do support the conclusion that when students are offered appropriate mobile resources then they will make use of them. Due to the high use of $\mathrm{mp} 3 / \mathrm{mp} 4$ resources, teachers could consider using more podcasts and vodcasts as teaching materials. In previous studies about podcasts, the majority of students preferred to listen to podcasts on their laptop rather than using their MP3 player (Salomon et al., 2007; Carvalho et al., 2009). This preference may be due to an association of $\mathrm{mp} 3$ players with leisure rather than learning, a lack of broader adoption of mobile devices in education, or a reflection of an individual's everyday mobility and the places where they prefer to study.

\section{CONCLUSION}

Our research gives an international account of mobile device use from learners' perspectives, in relation to learning, social interaction, entertainment and work, with a view to helping researchers and educators incorporate the emerging learner practices into their plans for further research, development and designs for learning. We agree with Kennedy et al. 
(2008) that "an evidence-based understanding of students' technological experiences is vital in informing higher education policy and practice" (p. 109) since, as they point out, this will have implications for student access, equity and transition. We believe the insights gained from looking at learners' accounts of authentic experience are essential in improving understanding between learners and teachers as well as helping to shape future plans for the use of technology in education.

Whatever their age, learners constitute a pool of valuable experience and expertise in the use of mobile technologies. As a collective body, they own, or have access to, some of the latest mobile devices and applications. Pressures of study and assignment deadlines lead them to seek effective solutions to immediate needs on the go. If they are studying in different university departments, they are also in a good position to share experience freely across discipline boundaries, which is something that educators may find much more challenging to do.

Straub (2009) suggests that "the future of adoption research should focus not just on adoption and implementation of information technology in the formal organization but how individuals understand, adopt, and learn technology outside of the formal organization" (p. 646). We concur with this view, while also heeding his plea to avoid a 'proadoption bias', that is, the assumption that the goal is to disseminate information about innovations specifically so that they might be adopted by others (Rogers, 1995). Whilst some practices are worth adopting more widely, others may not merit it, but being better informed about evolving practices has to be a worthwhile goal.

The present investigation leads to various hypotheses for future research, including possible differences in communication choices depending on gender and age. Given the widespread use of SMS demonstrated in our study, we would advocate more research on how language use is adapted for texting (Hård, 2002; Baron, 2008). Furthermore, since the use of a mobile device represents a new technological means of reading books, articles and news, this might have an impact on how, and how much, students read, however further research would be needed.

The landscape of mobile devices has changed since our survey with some devices (standalone PDAs) becoming almost extinct and others (handheld GPS) endangered. The functionality of these devices has been incorporated into smart mobile phones and tablet devices. Not only are mobile devices becoming more affordable and thus more widely used, they also have enhanced connectivity using Wi-Fi. Our study has considered the broad use of mobile devices amongst students; the next research step should be to examine the specific applications that students use for learning, especially those produced by universities. How, where and when do students make use of these applications? In what ways do the applications contribute to the students' overall learning? If mobile applications become a significant part of a university's offering, does this disadvantage some students and, if so, how? Furthermore, as mobile devices become more widespread there will be new types of applications and probably substantial changes in practice which cannot necessarily be foreseen but which will also provide interesting directions for further research.

\section{ACKNOWLEDGMENTS}

The authors would like to thank the students and alumni who completed the questionnaire for this study, from: Chalmers University of Technology, Hong Kong University, Leeds University, the University of Minho, The Open University and the University of Wollongong. They would also like to thank Donna Phillips from The Open University's Institute of Educational Technology who set up and administered the questionnaire.

\section{REFERENCES}

Baron, N. S. (2008). Always On: Language in an Online and Mobile World. Oxford, UK: Oxford University Press. 
Bradford, K. T. (2010). Mobile device users drive Wi-Fi hotspot proliferation. Retrieved from http:// blog.laptopmag.com/mobile-device-users-drive-wifi-hotspot-proliferation

Bruns, A. (2005). 'Anyone can edit': Understanding the produser. Retrieved from http://snurb.info/index. php?q=node $/ 286$

Carvalho, A. A., Aguiar, C., Santos, H., Oliveira, L., Marques, A., \& Maciel, R. (2009). Podcasts in Higher Education: Students and Teachers Perspectives. In Tatnall, A., \& Jones, A. (Eds.), Education and Technology for a Better World (pp. 417-426). Berlin, Germany: Springer. doi:10.1007/978-3-64203115-1_44

Christakis, N., \& Fowler, J. (2009). Connected - The Amazing Power of Social Networks and How they Shape Our Lives. London, UK: Harper Press.

Cohen, L., Manion, L., \& Morrison, K. (2000). Research Methods in Education (5th ed.). London, UK: RoutledgeFalmer. doi:10.4324/9780203224342

Conole, G. (2007). Describing learning activities: Tools and resources to guide practice. In Beetham, H., \& Sharpe, R. (Eds.), Rethinking Pedagogy for a Digital Age: Designing and delivering e-learning (pp. 81-91). London, UK: Routledge.

Conole, G., de Laat, M., Dillon, T., \& Darby, J. (2008). 'Disruptive technologies', 'pedagogical innovation': What's new? Findings from an in-depth study of students' use and perception of technology. Computers \& Education, 50(2), 511-524. doi:10.1016/j. compedu.2007.09.009

Continental Research.(2008). Continental Research: The Autumn 2008 Mobile Phone Report. Retrieved from http://www.iabeurope.eu/

Gartner. (2010). Gartner Says Worldwide Mobile Phone Sales Grew 17 Per Cent in First Quarter 2010. Retrieved from http://www.gartner.com/it/ page.jsp?id=1372013

Hård, Y. (2002). Use and Adaptation of Written Language to the Conditions of Computer-Mediated Communication. Retrieved from http://www.ling. gu.se/ ylvah/dokument/eng_diss_abstract.pdf

Herrington, J., Herrington, A., Mantei, J., Olney, I., \& Ferry, B. (Eds.). (2009). New technologies, new pedagogies: Mobile learning in higher education. Wollongong, NSW, Australia: University of Wollongong.
ITU. (2009). Measuring the Information Society: ICT Development Index. 2009 edition. Retrieved from http://www.itu.int/ITU-D/ict/publications/ idi/2009/index.html

JISC. (2009). Effective Practice in a Digital Age: A guide to technology-enhanced learning and teaching. Retrieved from http://www.jisc.ac.uk/publications/ programmerelated/2009/effectivepracticedigitalage.aspx

Jones, C. R., Ramanau, R., Cross, S., \& Healing, G. (2010). Net generation or Digital Natives: Is there a distinct new generation entering university? Computers \& Education, 54(3), 722-732. doi:10.1016/j. compedu.2009.09.022

Katz, J.E., \& Aakhus, M. (2002). Perpetual Contact: Mobile Communication, Private Talk, Public Performance. Cambridge, UK: Cambridge University Press. doi:10.1017/CBO9780511489471

Kennedy, G. E., Judd, T. S., Churchward, A., Gray, K., \& Krause, K.-L. (2008). First Year Students' Experiences with Technology: Are they really Digital Natives? Australasian Journal of Educational Technology, 24(1), 108-122.

Kukulska-Hulme, A., \& Pettit, J. (2006, October 2325). Practitioners as innovators: emergent practice in personal mobile teaching, learning, work and leisure. In Proceedings of Mlearn '06: Mobile Learning Conference, Banff, AB, Canada.

Kukulska-Hulme,A., \& Pettit, J.(2009). Practitioners as innovators: Emergent practice in personal mobile teaching, learning, work and leisure. In Ally, M. (Ed.), Mobile Learning: transforming the delivery of education and training (pp. 135-155). Athabasca, AB, Canada: Athabasca University Press.

Oblinger, D. G., \& Oblinger, J. L. (2005). Educating the Net Generation. Retrieved from http://www. educause.edu/educatingthenetgen

OFTA. (2009). Key Telecommunications Statistics. Hong Kong: Office of the Telecommunications Authority of Hong Kong. Retrieved from http://www. ofta.gov.hk/en/datastat/key_stat.html

Pettit, J., \& Kukulska-Hulme, A. (2007). Going with the grain: mobile devices in practice. Australasian Journal of Educational Technology, 23(1), 17-33.

Prensky, M. (2001). Digital Natives, Digital Immigrants, Part 2. Do they Really Think Differently? Horizon, 9(6). 
Prensky, M.(2009). H. Sapiens Digital: From Digital Immigrants and Digital Natives to Digital Wisdom. Innovate, 5(3).

PTS. (2009). The Swedish Telecommunication Market - First half year 2009-PTS-ER-2009: 29.

Retrieved from http:/www.pts.se/en-gb/Documents/ Reports/Telephony/2009/Svensk-telemarknadforsta-halvaret-2009---PTS-ER-200929/

Rogers, E. M. (1995). Diffusion of innovations (4th ed.). New York, NY: Free Press.

Salmon, G., Nie, M., \& Edirisingha, P. (2007). Informal Mobile Podcasting and Learning Adaptation (IMPALA). Leicester, UK: Beyond Distance Research Alliance, University of Leicester.

Stockwell, G. (2008). Investigating learner preparedness for and usage patterns of mobile learning. ReCALL, 20(3), 253-270. doi:10.1017/ S0958344008000232

Straub, E. (2009). Understanding Technology Adoption: Theory and Future Directions for Informal Learning. Review of Educational Research, 79, 625-649. doi:10.3102/0034654308325896

Tapscott, D. (1998). Growing up digital: The Rise of the Net Generation. New York, NY: McGraw Hill.
Tapscott, D. (2008). Grown Up Digital: How the Net Generation is Changing Your World. New York, NY: McGraw Hill.

Trinder, J. (2005). Mobile technologies and systems. In Kukulska-Hulme, A., \& Traxler, J. (Eds.), Mobile learning: A handbookfor educators and trainers (pp. 7-24). London, UK: Routledge.

Trinder, K., Guiller, J., Margaryan, A., Littlejohn, A., \& Nicol, D. (2008). Learning from digital natives: bridging formal and informal learning. Retrieved from http://www.heacademy.ac.uk/assets/York/ documents/LDN\%20Final\%20Report.pdf

Walker, A. (2009). Confessions of a Reluctant Podcaster. In V. King, C. Broughan, L. Clouder, F. Deepwell, \&A. Turner(Eds.), Academic Futures (pp. 209-222). Newcastle-upon-Tyne, UK: Cambridge Scholars Publishing.

Walls, S. M., Kucsera, J. V., Walker, J. D., Acee, T. W., McVaugh, N. K., \& Robinson, D. H. (2010). Podcasting in education: Are students as ready and eager as we think they are? Computers \& Education, 54(2),371-378. doi:10.1016/j.compedu.2009.08.018

Wenger, E. (2010). SIKM community presentation online. Theme: Rethinking Ourselves (KM People) as Technology Stewards. Retrieved from.http:// technologyforcommunities.com/ 


\section{APPENDIX}

Figure 1. Questionnaire

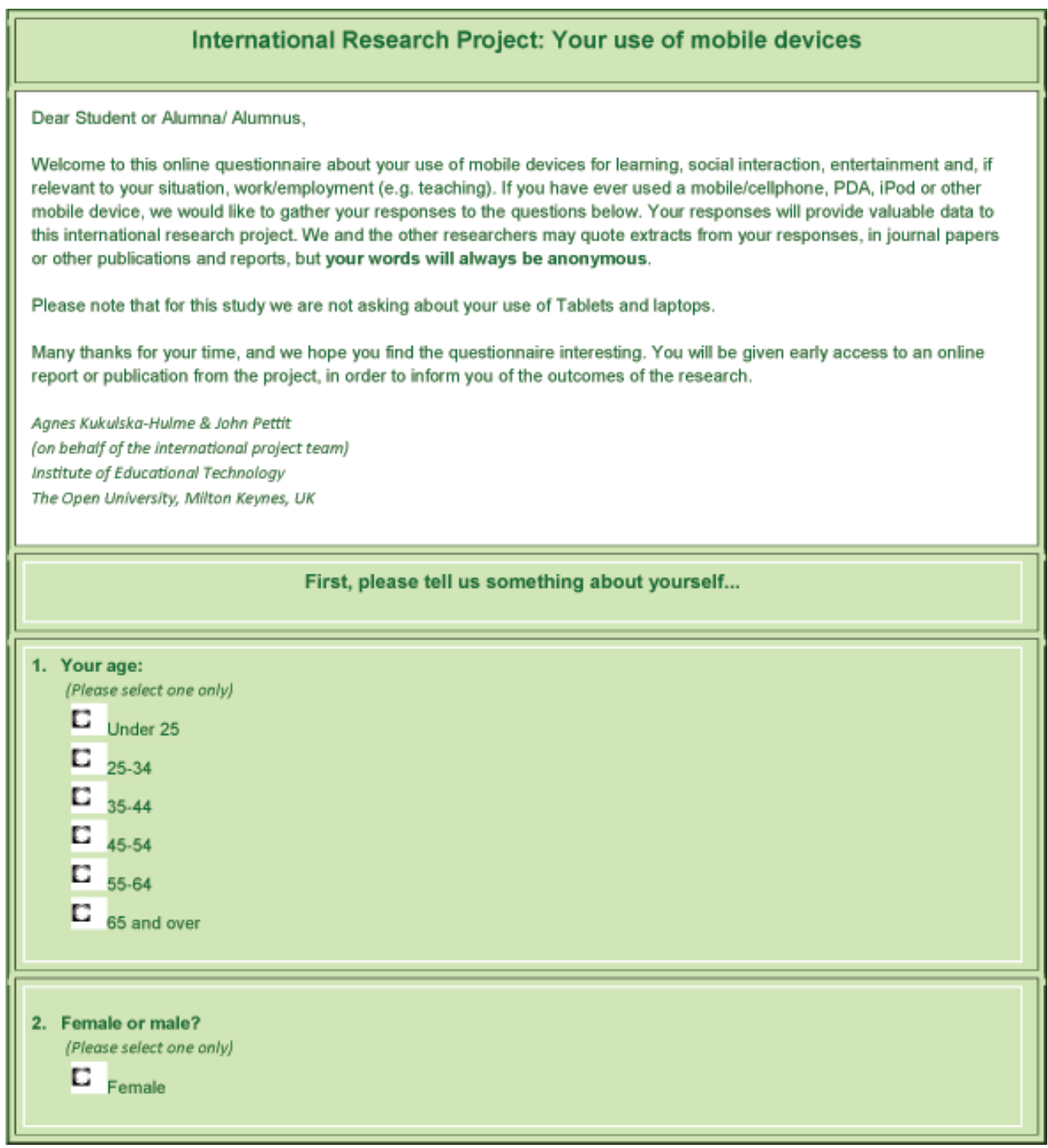




\section{Figure 2. Questionnaire continued}

3. In which country do you spend most/all of your time?

Please specify here:

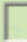

4. If you work, please state your job or profession:

Please specify here:

\section{Now a longer section...}

Your use of mobile devices - Now or in the past

5. Have you used a mobile phone ('cellphone')? (We ask about smartphones in Q6.) (Please select one only)

C No-Pleasego to Q5.

C Yes

If 'Yes', please give us one or more examples in detail to show how you use(d) it for... ....your learning:

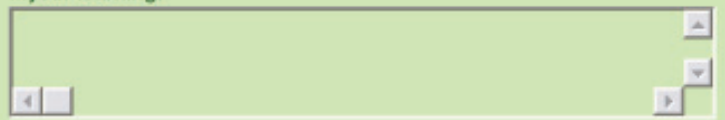

...social interaction:

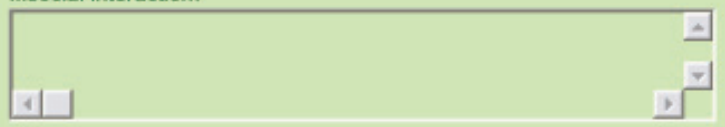

...entertainment/quizzes/games:

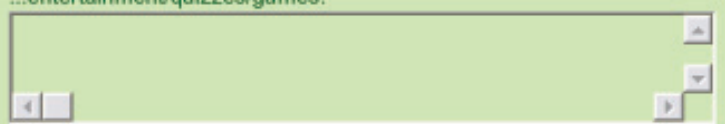


Figure 3. Questionnaire continued

6. Have you used a smartphone (i.e. mobile phone/PDA in one device, e.g. Blackberry, iPhone)? (Please select one only)

C No-Pleasego to 07 .

C Yes

If 'Yes', please give us one or more examples in detail to show how you use(d) it for... ...your learning:

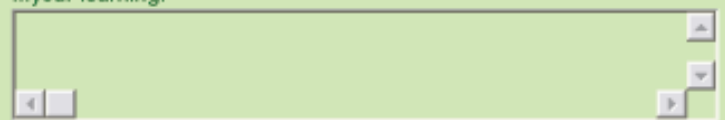

...social interaction:

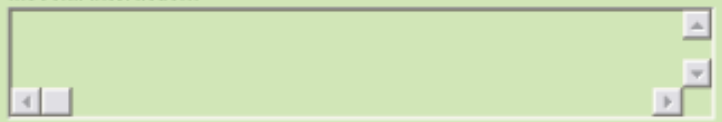

...entertainment/quizzes/games:

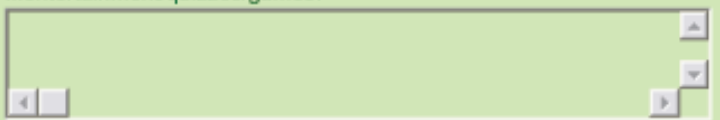

...workteaching:

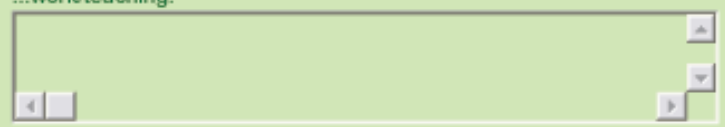


Figure 4. Questionnaire continued

7. Have you used a PDA (e.g. Palm, HP iPAQ, iPod Touch)?

(Please select one only)

C No-please go to Q8.

C Yes

If 'Yes', please give us one or more examples in detail to show how you use(d) it for... ...your learning:

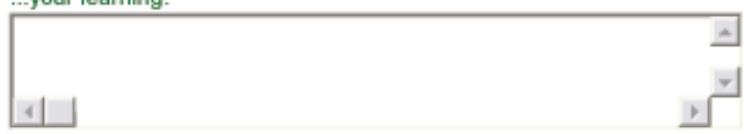

...social interaction:

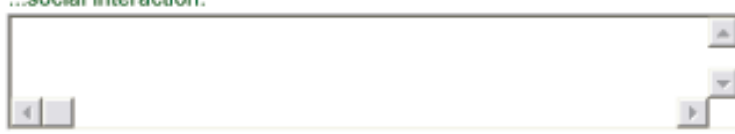

...entertainment/quizzes/games:
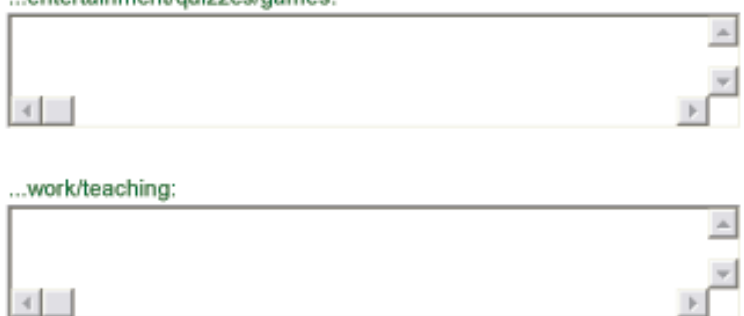
40 International Journal of Mobile and Blended Learning, 3(1), 18-52, January-March 2011

Figure 5. Questionnaire continued

8. Have you used an mp3-player or mp4-player (e.g. iPod)?

(Please select one only)

C No-please go to Q9.

C Yes

If 'Yes', please give us one or more examples in detail to show how you use(d) it for... ...your learning:

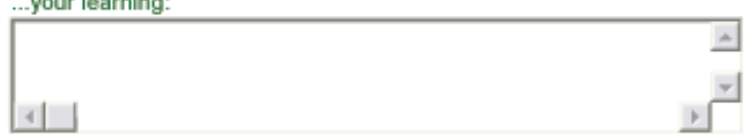

...social interaction:

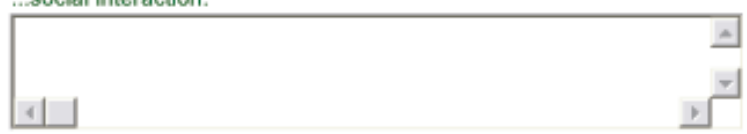

...entertainment/quizzes/games:

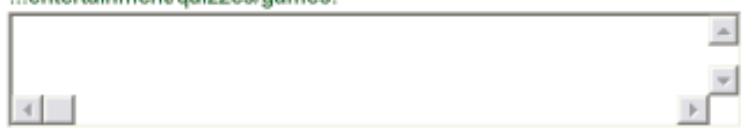

...work/teaching:

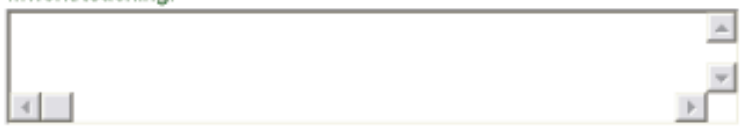


Figure 6. Questionnaire continued

\section{Being part of groups and communities}

9. Do you use a mobile device to be part of one or more groups or communities? These can be formal or informal groups or communities, relating to friends, leisure, family, study, work etc. (Please select one only)

C No-Please go to 012 .

C Yes

If 'Yes'...

....please tell us about the purposes of one such group or community:

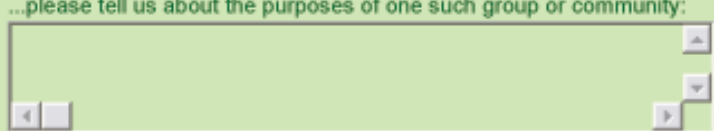

...please also tell us which device(s) you use and explain how you use it/them:

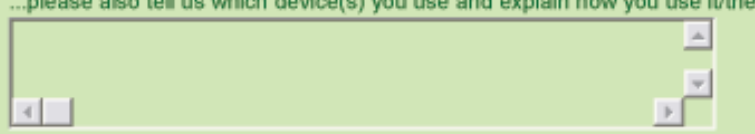

10. What are the main benefits for you of being part of this group or community? Please specify here:

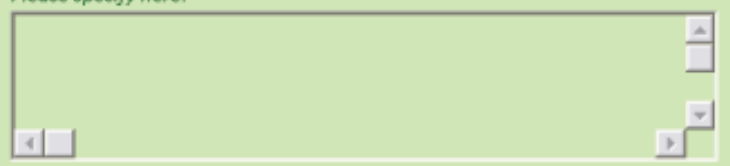

11. Could you be part of this group/community if you did not use a mobile device? (Please sefect one only)
C No
C Yes 
Figure 7. Questionnaire continued

\section{Specific uses for mobile devices}

(When you finish this section, you will have nearly completed the questionnaire)

12. Below are some things that you may have done 'with mobile devices' (phone, PDA, iPod etc - but we

are not asking about use of Tablets or laptops). For each activitiy, please select the button that most

accurately shows how often you do/did it. Or, if appropriate, select 'never'.
Browsing websites:
(Please select one only)
C Several times a day
E Once or twice a day
C A few days a week
C Once a week
C Once a month
C Less than once a month
C Never

Reading an e-book:

(Please select one only)

C Several times a day

C Once or twice a day

C A few days a week

C Once a week

C Once a month

C Less than once a month

C Never

Reading e-news:

(Please select one only)

C Several times a day

C Once or twice a day

C A few days a week

C Once a week

$\mathbf{C}$ Once a month

C Less than once a month

C Never 
Figure 8. Questionnaire continued
Reading an academic paper:
(Please select one oniy)
C Several times a day
C Once or twice a day
E A few days a week
C Once a week
C Once a month
C Less than once a month
C Never
Making a video clip:
(Please select one only)
C Several times a day
C Once or twice a day
C A few days a week
C Once a week
C Once a month
C Less than once a month
C Never

Viewing a video clip (one you or your friends have made):
(Please select one only)
C Several times a day
C Once or twice a day
C A few days a week
C Once a week
C Once a month
C Less than once a month
C Never 
Figure 9. Questionnaire continued

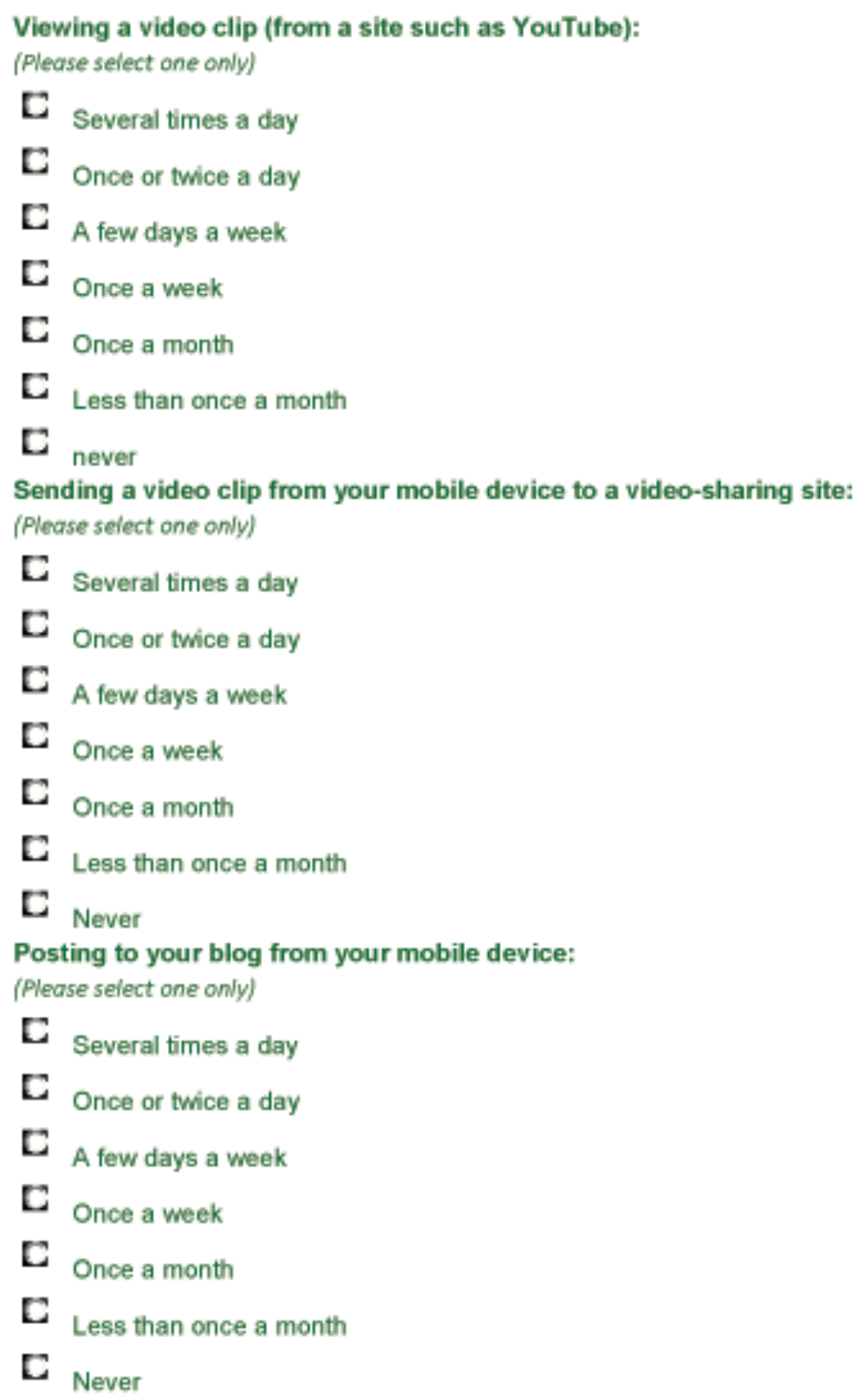


Figure 10. Questionnaire continued

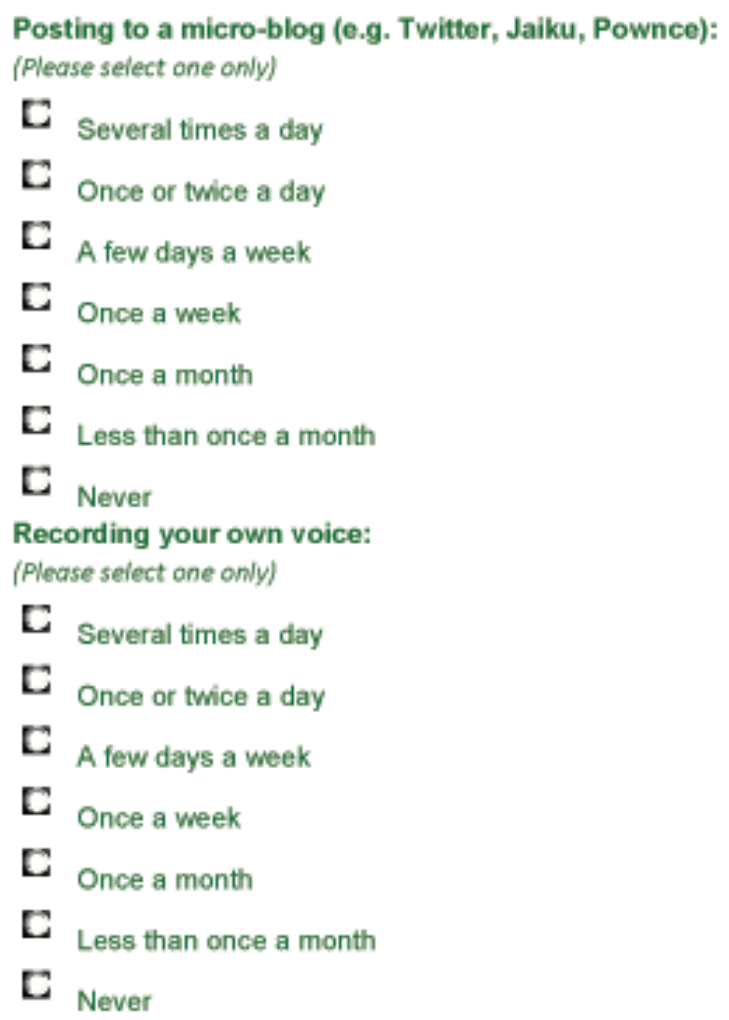


Figure 11. Questionnaire continued

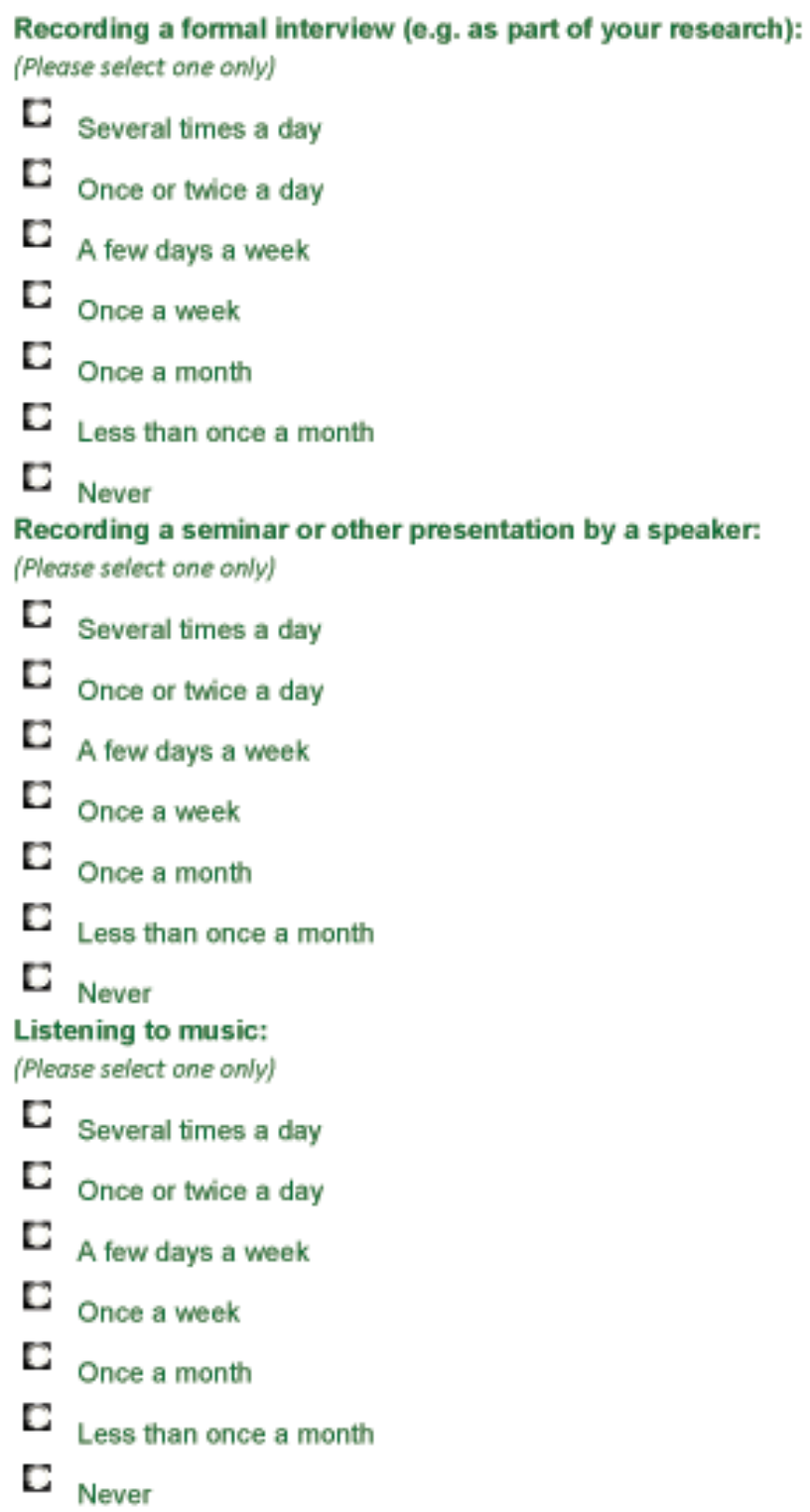


Figure 12. Questionnaire continued
Listening to podcasts:
(Please select one ony)
C Several times a day
C Once or twice a day
E. A few days a week
C Once a week
C Once a month
C Less than once a month
C Never

Accessing a social networking site (e.g. Facebook, MySpace, Bebo etc.):

(Please select one only)

C Several times a day

C Once or twice a day

C A few days a meek

C Once a week

C Once a month

C Less than once a month

C Never

Taking a photograph:

(Please select one only)

C Several times a day

C Once or twice a day

C A few days a week

C Once a week

C Once a month

C Less than once a month

C Never 
Figure 13. Questionnaire continued

Sending a photograph from a mobile device to a photosharing or social networking site (e.g. Flickr,

Facebook, etc.):

(Please select one only)

C Several times a day

C Once or twice a day

C A few days a week

C Once a week

C Once a month

C Less than once a month

C Never

Sending a photograph from a mobile device direct to friends or family:

(Please select one only)

C Several times a day

C Once or twice a day

C A few days a week

C Once a week

C Once a month

C Less than once a month

C Never

Accessing a wiki (e.g. Wikipedia):

(Please select one only)

C Several times a day

C Once or twice a day

C A few days a meek

C Once a week

C Once a month

C Less than once a month

C Never 
Figure 14. Questionnaire continued

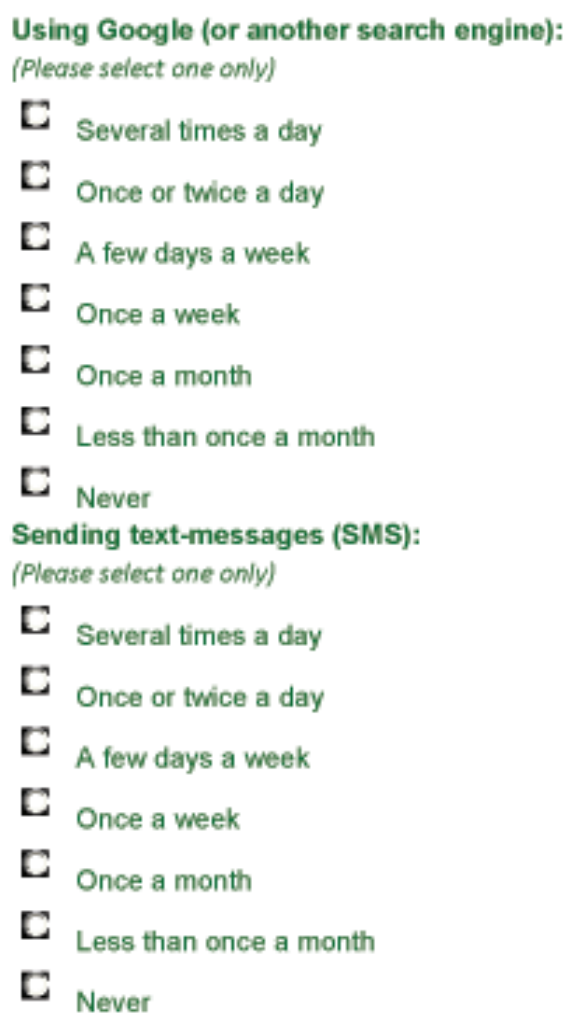

Using a mobile device to make notes:

(Please select one only)

C Several times a day

C Once or twice a day

C A few days a week

C Once a week

C Once a month

C Less than once a month

C Never 
Figure 15. Questionnaire continued

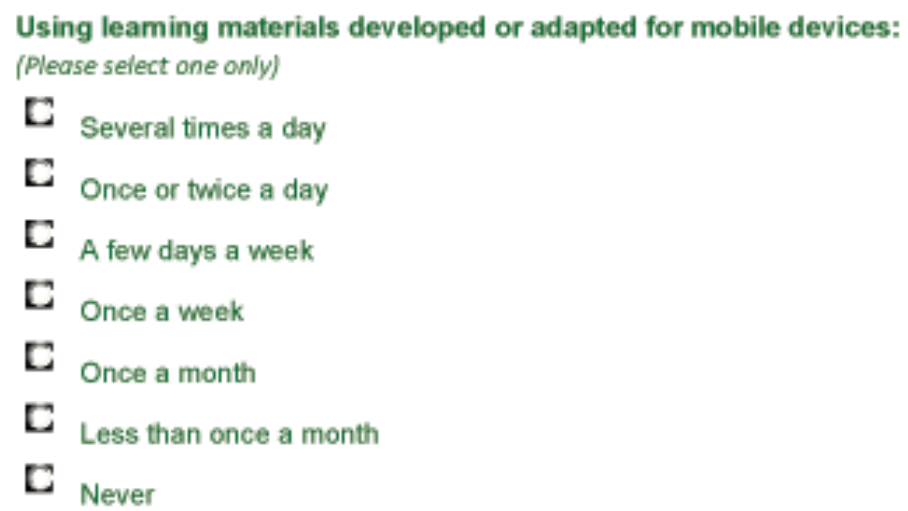




\section{Figure 16. Questionnaire continued}

13. In the questionnaire so far, we may have forgotten to ask about some of the ways in which you use mobile devices now or have used them in the past. Please tell us here about any other way in which you use(d) them?

Please specify here:

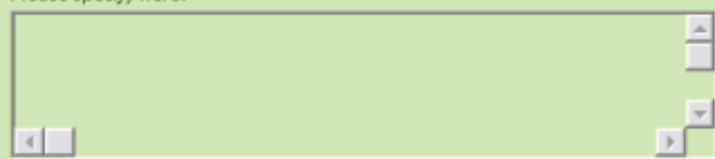

Finally...

Mobile devices for learning: What's special, what's a problem?

14. If you use, or have used, mobile devices for learning of any kind, what do you consider to be new and innovative about your experience of this form of learning?

Please specify here:

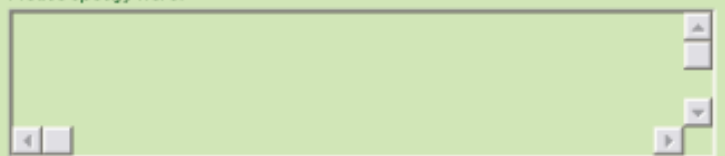




\section{Figure 17. Questionnaire continued}

15. What is the single biggest problem or disadvantage that mobile devices bring you in relation to your learning? In which context, and using which device?

Please specify here:

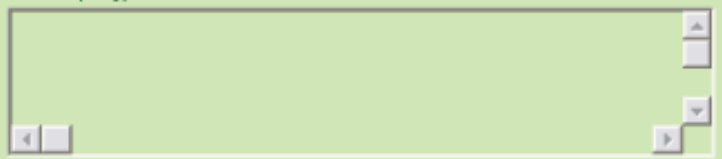

We might like to ask you more about your use of mobile devices. If you would be interested in considering this, please give your name and email address:

Name:

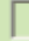

Email address:

Thank you very much indeed for your time and effort in completing this questionnaire.

Please submit your responses by clicking on the button below. 